\title{
Queratosis seborreica
}

\author{
Seborrheic keratosis
}

Vanessa E. Mendez Mathey 1,a.

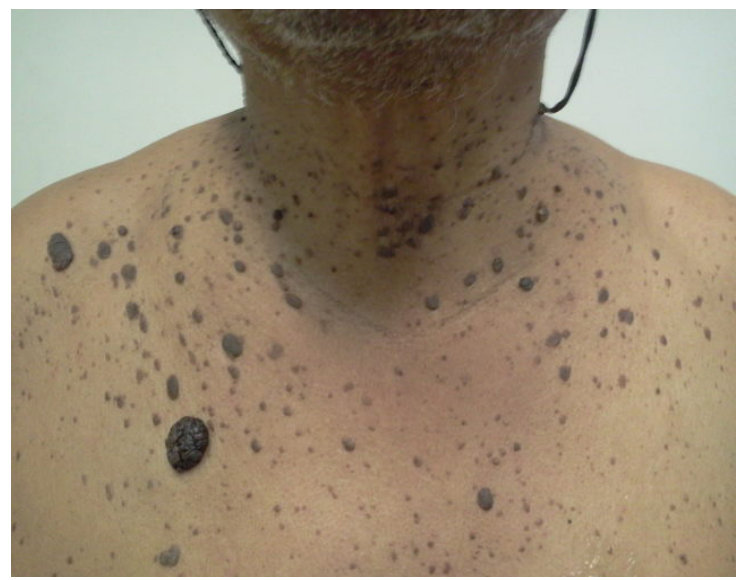

La queratosis seborreica corresponde a lesiones cutáneas benignas y frecuentes, se presentan en ambos sexos, generalmente en la tercera década de la vida, aumentando su número con la edad; pueden ser aisladas o múltiples siguiendo un patrón arboriforme cuando se localizan en el cuello, tórax y espalda, pudiendo presentarse también en el rostro y extremidades superiores con excepción de mucosa, palmas y plantas de los pies. Clínicamente se manifiesta como maculas, pápulas o placas hiperqueratosicas bien delimitadas, pigmentadas o no, pudiendo ser endofíticas o exofiticas. Son asintomáticas, pero en ocasiones pueden ser pruriginosas o sensibles a la palpación. Su patogenia es desconocida, se postula que en pacientes con cierta predisposición pueden liberarse productos de una neoplasia de fondo, estimulando la proliferación de queratinocitos. Se han propuesto varias formas clínicas: queratosis seborreica común, dermatosis papulosa nigra, pediculada, plana y en estuco. La aparición súbita de múltiples queratosis seborreica puede ser un signo paraneoplasico (signo de Leser-Trelat) relacionado con tumores gastrointestinales, de mama, pulmón, próstata, melanoma maligno, micosis fungoide y neoplasia linfoproliferativa. La queratosis seborreica no tiende a la degeneración maligna, y raramente se asocia a otras neoplasias cutáneas.

Seborrheic keratosis are benign cutaneous lesions common in both sexes starting usually at the third decade of life. The number of lesions increase with age, it may present with single or multiple lesions specially if located in the thorax and neck, other possible locations are the face and upper limbs, areas not affected are mucosal areas and palms and soles. Clinical manifestations include well demarcated macules, papules or plaque like lesions with keratosis, either pigmented or not, and with endophytic or exophytic patterns. Lesions are usually asymptomatic but in occasions may present with pruritus or pain on palpation. The pathogenesis is unknown; it has been hypothesized that substances released by occult cancers may stimulate keratinocytes. There are several clinical forms; common seborrheic keratosis, dermatitis papular nigra, pedunculated, flat and stucco keratosis. The sudden onset of multiple seborrheic keratosis may be a paraneoplastic manifestation (sign of Leser-Trelat) of breast, lung, prostate, malignant melanoma, mycosis fungoides or lymphoproliferative cancers. Seborrheic keratosis does not evolve into malignant degeneration and it is rarely associated with other cutaneous cancers. 